Електронне наукове фахове видання з економічних наук «Modern Economics», №17 (2019), 6-10 https://modecon.mnau.edu.ua | ISSN 2521-6392

JEL Classification: M37

DOI: https://doi.org/10.31521/modecon.V17(2019)-01

Antonova Olga, PhD in Social Communications, Associate Professor of Department of Marketing, National University of Food Technologies, Kyiv, Ukraine

ORCID ID: 0000-0003-3213-8699

e-mail: antonova.olga.edu@gmail.com

\title{
Three Ways to Use ASMR-Technologies in Modern Advertising and Marketing
}

\begin{abstract}
Introduction. The article is devoted to the peculiarities of autonomous sensory meridional response technologies application in marketing and advertising communication. In the context of the modern information oversaturation of a person, it is a promising technology of advertising due to its anti-stress orientation and indirect influence on the subconscious of recipients, which helps to create a favourable perception of an advertised product by the audience.

Purpose. The aim of this study is to consider three methods of ASMR-technologies application in global and, in particular, Ukrainian advertising and marketing. The subject of the research is the specificity of the ASMR-technologies application in advertising videos and the advertising potential of ASMR-video. The object of the research consists of videos of foreign and domestic ASMR-bloggers on YouTube and commercials in which these technologies are used. The scientific originality of the research is conditioned by the fact that usage of ASMR-influence in the field of advertising and marketing has not yet been thoroughly investigated, and therefore requires scientific study.

Results. After the analysis of global trends in the development of advertising technologies, it is concluded that autonomous sensory meridional response is becoming a popular trend in both online video content and commercials. Based on the application of specific sound, visual and communicative triggers, video products of this type cause spectators to experience specific psychophysiological reactions, in particular, relaxation, pleasant tingling, goose pimples, and a lowering of tension. Fixing of positive associations, the desire to watch long video content multiple times, and conscious orientation towards suggestiveness all make ASRM-technology attractive for usage in advertising and marketing. Three different ways to use this technique for advertising purposes were distinguished: the placement of advertising on popular channels of ASMR-enthusiasts, collaboration with video bloggers aiming to create native advertising, and to make a kind of product placement in their vlogs, and the creation of commercial advertising full of ASMR-triggers. In Ukraine, the usage of autonomous sensory meridional response technology in video content has gained popularity on YouTube and Instagram (which is proved by the large number of content views and followers) but has not yet become an instrument of influence in domestic commercial video advertising, unlike in the global advertising market.
\end{abstract}

Conclusion. ASMR-advertising should be considered as a promising tendency for the development of domestic advertising in the perspective of the global trends in this industry development and the possibilities of soft effective influence on the recipients provided by the autonomous sensory meridional response technology.

Keywords: autonomous sensory meridian response, ASMR, video advertising, online advertising, video content, psychophysiological responses, suggestiveness.

\section{Удк 659.1}

Антонова О. В., кандидат наук із соціальних комунікацій, доцент кафедри маркетингу, Національний університет харчових технологій, м. Київ, Україна

\section{Три шляхи застосування АСМР-технологій у сучасній рекламі та маркетингу}

Анотація. Статтю присвячено особливостям застосування у рекламній комунікації та маркетингу технологій автономної сенсорної меридіональної реакції. Метою роботи є розгляд трьох способів застосування АСмРтехнології у світовій та, зокрема, украӥнській рекламі й маркетингу. Предметом дослідження є специфіка застосування різновидів АСМР-технології у рекламних відеороликах та рекламний потенціал АСМР-відео. Об'єктом дослідження стали відеоматеріали закордонних та вітчизняних АСМР-блогерів на каналі Үоитиве та рекламні ролики із використанням цієї технологї̈. Наукова новизна дослідження зумовлена тим, що використання АСМР-впливу у галузі реклами та маркетингу ще не були грунтовно досліджені.

У ході дослідження проаналізовано можливості та шляхи застосування технологій АСМР у сфері реклами та маркетингу, зокрема створення як рекламних відео з окремими АСМР-тригерами, так і повноцінних АСМР-відеороликів та перспектив співпраці рекламодавців з АСМР-тистами. Було здійснено розгляд особливостей використання АСМР у вітчизняному медійному та інтернет-просторі в контексті світових тенденцій.

Уході дослідження було виокремлено три способи використання цієї техніки з рекламною метою: розміщення реклами на популярних каналах АСМР-тистів, співпраця з відеоблогерами з метою створення нативної реклами та свого роду продакт плейсменту в їхніх влогах, створення комерційної реклами, насиченої АСмР-тригерами. В Україні застосування технології автономної сенсорної меридіональної реакції у відеоконтенті набули популярності у мережах Youtube ma Instagram (про що свідчить значна кількість переглядів контенту та фоловерів), однак ще не стали інструментом впливу у вітчизняній комерційній відеорекламі, на відміну від світового рекламного ринку.

Стаття надійшла до редакції: 07.09.2019

Received: 07 September 2019 
АСМР-рекламу варто розглядати як перспективну тенденцію розвитку вітчизняної реклами з огляду на світові тенденції цієї галузі та можливості м'якого ефективного впливу на реципієнтів, які надає технологія автономної сенсорної меридіональної реакції завдяки вираженому релакс-ефекту та зниження напруги з огляду на закріплення позитивних асоціацій, викликання бажання переглядати відеоконтент значного хронометражу кілька разів.

Ключові слова: автономна сенсорна меридіональна реакція; АСМР; відеореклама; інтернет-реклама; відео контент; психофізіологічні реакції; сугестивність.

Problem scope. A modern consumer functions in the conditions of daily mass information influence, which causes inevitable changes in the cognitive, motivational and philosophical spheres of personality. The excess information that can cause stress causes the need to find new advertising tools, more attractive to the consumer.

To achieve its goal, a promotional message must be noticed by a potential consumer, separated from the dense stream of daily media information, decoded and memorized. As a result, the relaxing, anti-stress orientation of the advertising product, the orientation to the indirect influence on the subconscious, which helps to overcome the barrier of human psyche rejection of excessive information, and the formation of a favourable perception of the advertised product by the audience becomes relevant.

In such circumstances, consideration of the perspectives for the usage of so-called autonomous sensory meridian response technology (abbreviated ASMR) in the media as the newest way to influence softly the minds of the audience with a clear relaxation effect and its introduction into advertising seems topical and relevant.

The aim of the research. The aim of our study is to consider three ways of APMR-technologies usage in global and, in particular, Ukrainian advertising and marketing. The realization of the aims involves solving several tasks, in particular, outlining the peculiarities of influence of ASMR-technologies on the audience and its variants, analysis of its application possibilities in the advertising industry and perspectives of cooperation with ASMRenthusiasts, consideration of the features of ASMR usage in the domestic media and internet space in the context of global trends.

The subject of the research is the specificity of the ASMR-technologies application in advertising videos and the advertising potential of ASMR-video. The object of the research consists of videos of foreign and domestic ASMRbloggers on YouTube and commercials in which these technologies are used.

Analysis of recent research and publications. Autonomous sensory meridian response or ASMR is a feature of perception, characterized by the emergence of a number of "physiological states which are induced by the set of specific actions" [1, p. 80], "a clear, pleasant tingling sensation on the skin of the head or other parts of the body in response to certain visual, auditory and (or) cognitive stimuli" [2, p. 173]. The term was proposed in 2010 by J. Allen, one of the organizers of the international community dedicated to the ASMR on the social network Facebook [3].
Speaking about previous studies of ASMR, we note that it has become the subject of interest of domestic and foreign scientists from various fields of science, in particular, psychology, pedagogy, sociology. Thus, scientists S. Novella and R. Gallagher considered possible physiological causes of the sensation, called ASMR, made a description of the states and analysed the triggers of this response $[4 ; 5]$. E. Barratt and N. Davis have paid attention to such the feature of ASMR that it provides temporary improvement in well-being for those with depression or stress [6]. The Ukrainian researcher V. Khomenko analysed the impact of these techniques on different groups of people and drew attention to ASMRmechanisms usage for psychotherapeutic purposes [2]. The therapeutic effect of ASMR also became the subject of research by E. Apazidi, which concluded that the most significant impact of these technologies is carried out on persons who suffer from stress, particularly students [7]. The Russian scientist D. Shkarin has carried out a thorough analysis of the psychosocial levels of ASMR-influence, paying attention to the fundamental difference between the action of sensory triggers of ASMR and the influence of traditional mass media [1].

However, we should mention that the use of ASMRinfluence in advertising has not yet been thoroughly studies and therefore requires scientific exploration.

Main results and their substantiation. By the term of ASMR-content, we mean videos, which are distributed mainly on internet networks, that focus on putting the audience in a kind of pleasant relaxation state, accompanied by physiological pleasure caused by sound and visual triggers. Such videos are designed for long-term viewing, they are expressly slow, unhurried, even static, as opposed to the traditional dynamic "clipping" organization of mass media materials. Most of the ASMRvideos have long running times (from 20 minutes to several hours), but due to the physiological and emotional responses they cause, viewers are happy to watch them, even several times, for relaxation.

We suggest dividing all triggers that cause an autonomous sensory meridian response into several groups:

a) vocal, which include whisper-quiet voices and soft slow speech; breathing sounds, breathing into a microphone, smacking lips and tongue;

b) noises, i. e. caused by interaction with objects, such as soft rumbling, crunching of packages, cellophane in the hands; knocking and the light scratching of nails or objects on textured surfaces, such as wood; the rustle of pages; and meals (so-called mukbangs) etc.; 
c) visual-tactile, by which we mean showing the process of allpying makeup, hair care, combing; smooth hand movements; touching viscid or soft bright substances; their crumbling or cutting;

d) communicative, a kind of role-play depicting communication situations.

We would like to emphasize that in ASMR-videos, a combination of these triggers is commonly used. Since there is no single trigger that would cause ASMR in all the people, combining multiple triggers increases the likelihood of causing an audience response.

ASMR-content has become widespread in recent years. In particular, today there are over 6 million videos on Instagram with the hashtag \#asmr, which is recognized as the main trend of 2018 on this social network [8]. On YouTube, searching produces more than 12 million videos of this type with a large number of views and supporters. For example, the channel of one of the most popular ASMR-enthusiasts, ASMR Darling, has over 2.4 million subscribers and the most popular video has received over 30 million views [9]. Her colleague at Gentle Whispering ASMR has over 1.6 million subscribers, and the most popular video has been viewed 21 million times [10].

There are also popular ASMR-bloggers in Ukraine. The channel of the Ukrainian ASMR-enthusiast HeyHelen ASMR has about 474 thousand followers. She is in the list of top 250 Ukrainian vloggers and views of her most popular video reach 3 million [11]. The ASMR nikinice vlogger's channel has nearly 50,000 subscribers, and its popular videos have been viewed more than 200,000 times [12]. Olga Khodos ASMR has a YouTube channel with over 5,000 subscribers, with the most popular videos receiving 35,000 views [13].

Features of ASMR-videos, such as popularity, the relaxation anti-stress effect, and the stimulation of rewatching, make the idea of such content usage for advertising purposes attractive. So, nowadays, this area is being actively exploited by advertisers. Thus, according to SocialBlade, well-known blogger Makenna Kelly, author of the ASMR-channel Life with MaK with 1.3 million subscribers, receives about $\$ 1000$ a day for advertising [14].

There are several ways to use the ASMR-technologies in advertising which leading companies in the world apply.

The first, most obvious, is to advertise on YouTube channels of popular ASMR-enthusiasts. Due to the high level of reach and the possibility of targeting the audience of these channels (according to research, $77 \%$ of the audience are interested in a healthy lifestyle, fitness, beauty [15]), such advertising is attractive to advertisers. There is no need to describe this in detail, since it is no different from advertising on video channels of other popular bloggers.

The second way that has become relevant both in the world and in Ukraine is the direct cooperation of advertisers with ASMR-enthusiasts. It can happen in a number of ways, including offering your product for video shoots, which varies from native advertising to product placement, or arranging direct advertising from a blogger. For example, in YouTube videos with ASMR-content, the topic of self-care is very popular, which allows you to present cosmetics easily, to show the audience its texture and color, and to inspire the audience to try a particular product.

For example, the channel called ASMR Ppomo, which has 1.7 million subscribers, specializes in the display of various manipulations with decorative cosmetics and care products. Live videos (mostly longer than an hour), in which a girl opens and closes a lipstick, imitates its application on the face of the viewer, draws with the cosmetics on paper, demonstrating texture and creating a specific rustle, have a significant number of views (up to 7 million). The brand of the used product is clearly visible in the frame [16]. There is also a separate segment of video content dedicated to pouring liquids, in particular beer, into a glass, where bottles with labels are displayed in the frame.

The Ukrainian ASMR teams are also actively working with advertisers. As an example, already mentioned Olga Khodos, the author of Olga Khodos ASMR channel, often uses native advertising without referring to a specific brand in the description below the video. The topic of videos (the same way as with her foreign colleagues) is usually self-care and makeup. The blogger talks about the cosmetics she uses, not naming the brand of cosmetics, but the packaging with the logo is visible. In particular, her ASMR-videos feature the following brands: Carner Barselona, Yves Rosher, Labello, Bell, Dior, Ralf Lauren, L'Oreal [13]. The ASMR-enthusiast also uses direct advertising in several commercials. In one of them, for example, Urban Decay cosmetics are presented, and the video shows information about the brand, although there is no link to the brand page. Another clip with a direct advertisement demonstrates the unpacking of the GoPro Hero 5 Black. In this video Olga Hodos rustles the packaging, taps her nails on the box with the camera, whispers about its usage. The description below the video gives the name of the product brand but without a link to the product page [13].

A bright example of direct advertising on the blogger's video channel is a video showing the scarves of the Ukrainian designer Natalia Kolpakova. In a short video (short in comparison with common length of ASMRvideos), which is about 11 minutes, Olga Hodos whispers about silk scarves, focusing on their tactile properties, slowly unfolding and folding them, stroking the fabric, bringing them close to her face, demonstrating how they glide softly from furniture, billow under gusts of wind, how they rustle. In the description below the video, she provides information about the products, and there is a link to the page of the scarf designer on the social network Facebook, as well as links to the page of her scarf collections exhibition. Today the video has over 5.5 thousand views [13].

The third way of usage of associative sensory meridian response in advertising is the conscious introduction of 
ASMR-triggers into commercial advertising, which would affect the subconscious, cause the viewers pleasant emotions and feelings, and contribute to memorizing of the advertising message. The level of ASMR-effect application can be different - starting from single triggers that "work" to convey the main advertising message, and to long commercials completely filmed on the basics of ASMR-technology.

As an example of single elements usage that can serve as triggers of associative sensory meridian response, we can consider a series of commercials by the cosmetic brand Maybelline New York, in which part of the slogan "Everyone is excited about you" (translation of the Ukrainian version of the slogan - O. A.) is spoken in a whisper.

However, the commercials that are based on the usage of ASMR-technologies seem to be more interesting. Videos with Autonomous Sensory Meridian Response were filmed to promote products by such famous brands as Coca Cola, KFC, IKEA, Tic Tac, Taco Bell, Dove Chocolate, Michelob Ultra and others. For example, in the video made for the brand of beer Michelob Ultra, famous actress Zoë Kravitz, imitating ASMR-enthusiasts, utters advertising text in a whisper. She is leaning close to the microphone, tapping her nails on the bottle and rolling it on the surface of the table. In addition, there are acoustic signs of the product itself: foam bubbles spitting, the sound of pouring into a glass, etc. [17]. ASMR-advertising for KFC has a humorous tone and parodies the style of communication and the most common action of video bloggers. Colonel Sanders slowly waves with a silk pocket square in the frame, demonstrates the softness and rustle of the fabric to the camera, speaks in a whisper and sometimes distracts to eat one of KFC products [18]. IKEA Corporation shot a full ASMR-video, which stands beyond the canon of commercial videos. Its significant duration (the video "Oddly IKEA: IKEA ASMR" lasts over 25 minutes [19]), slow change of plans, emphasized everyday actions shown in the video, deliberately smooth and slow manner, and quiet sounds all create a relaxation effect typical for videos with autonomous sensory meridian response. In this video the girl whose face is not shown (in the picture one can see only her hands), talks about the popular brand products which will be necessary for furnishing a cosy student room. She emphasizes tactile sensations and sounds of her interaction with objects (rustle of sheets, scratching on textured surfaces, tinkling of hangers in a wardrobe, rustle of boxes, squeaking of a table lamp, etc.) [19]. This video does not parody or borrow the techniques of ASMR-enthusiasts, but it is itself an example of video content of this type. The corporation, while releasing the video, stated that in using such ASMReffect it hoped to help students adapt more easily to the new environment and deal with stress and fatigue after a busy day [20].

If we talk about the Ukrainian advertising space, it should be acknowledged that ASMR-technologies have not yet been introduced and are still waiting for creative rethinking and development. Considering the impact potential of this technology, the wave of popularity in the world, and the positive effect on the consciousness of potential consumers, the usage of ASMR-triggers in advertising video production looks promising. In particular, focusing on global trends, we can point out the advisability of ASMR-technologies in the promotion of cosmetics and self-care products, beverages and food.

Conclusions and perspectives for further research. In analysing the global trends in the development of advertising technologies and marketing, we conclude that autonomous sensory meridian response is becoming a popular trend in both online video content and commercials. Based on the application of specific aural, visual, and communicative triggers, videos of this type invite spectators to experience specific psychophysiological responses, in particular, relaxation, pleasant tingling, goose bumps, and lowering of tension. The fixation of positive associations, the desire to watch long video content multiple times, and the conscious focus on suggestiveness all make ASTM-technology attractive for use in advertising and marketing. One can distinguish three ways this technique can be used for promotional purposes: to advertise on popular ASMRenthusiasts' channels, to collaborate with video bloggers for creation of native advertising or to make a kind of product placement in their vlogs, and to create commercial advertising rich with ASMR-triggers. In Ukraine, the usage of autonomous sensory meridian response technology in video content has gained popularity on YouTube and Instagram (as evidenced by the large number of content views and followers), but has not yet become a tool for influence in domestic commercial video advertising, unlike the global advertising market. This gap in the Ukrainian media space is not yet filled, so we consider ASMR-commercials as a promising tendency for the development of domestic advertising.

\section{References:}

1. Shkarin, D. L. (2018). Level Analysis of ASMR-Technology and Definition of its Meaning in the Modern Social Context. Vestnik Permskogo universiteta. Filosofiya. Psihologiya. Sotsiologiya, 1, 79-87. doi: 10.17072/2078-7898/2018-1-79-87 [in Russian].

2. Khomenko, V. I. (2017). Autonomous Sensory Meridional Response, Connection with Synesthesia. Empathy of Touch, Phonopsia, Eidetics and How They Influence ASMR-perception. Formation of ASMR-Therapy. Aktualni problemy suchasnosti $v$ konteksti sotsialno-psykholohichnoho znannia: materialy naukovo-praktychnoi konferentsii dlia studentiv, aspirantiv, vykladachiv (1 hrudnia 2016 roku) [Topical Problems of Modern Times in the Context of Social Psychological Knowledge: Materials of Scientific Practical Conference for Students, Postgraduate Students, Lecturers (1 ${ }^{\text {st }}$ December 2016)]. Irpin: University of the State Fiscal Service of Ukraine, 173-178 [in Ukrainian].

3. Richard, C. (2016). Interview with Jennifer Allen, the woman who coined the term, 'Autonomous Sensory Meridian 
Електронне наукове фахове видання з економічних наук “Modern Economics», №17 (2019), 6-10 https://modecon.mnau.edu.ua | ISSN 2521-6392

Response' (ASMR). ASMR University. Retrieved from: https://asmruniversity.com/2016/05/17/jennifer-allen-interview-coinedasmr/

4. Novella, S. (2012). ASMR. Neurologica. Mar. 12. Retrieved from: https://theness.com/neurologicablog/index.php/asmr/

5. Gallagher, R. (2016). Eliciting Euphoria Online: The Aesthetics of 'ASMR' Video Culture. Film Criticism. Jun, 40(2). Retrieved from: https://quod.lib.umich.edu/f/fc/13761232.0040.202?view=text;rgn=main. doi: http://dx.doi.org/10.3998/fc.13761232.0040.202

6. Barratt, E. L. \& Davis, N. J. (2015). Autonomous Sensory Meridian Response (ASMR): a flow-like mental state. PeerJ. Mar 26. Retrieved from: https://peerj.com/articles/851.pdf. doi: http://dx.doi.org/10.7717/peerj.851

7. Apazidi, E. V. (2018). Phenomenon of Autonomous Sensory Meridional Response. The development of medical sciences: problems and solutions : Conference Proceedings, April 27-28. Brno, 126-127 [in Russian].

8. Instagram Year in Review 2018 (2018). Info Center : website. Retrieved from: https://instagrampress.com/blog/2018/12/12/instagram-year-in-review-2018/

9. Channel ASMR Darling (2019). Retrieved from: https://www.youtube.com/channel/UCikebqFWoT3QC9axUbXCPYw.

10. Channel Gentle Whispering ASMR (2019). Retrieved from: https://www.youtube.com/user/GentleWhispering.

11. Channel HeyHelen ASMR (2019). Retrieved from: https://www.youtube.com/channel/UC5X7iRFTg24q8X01_W420Gg.

12. Channel ASMR nikinice (2019). Retrieved from: https://www.youtube.com/channel/UCG_Aemw5rJkAj2r7MaGfNFA.

13. Channel Olga Khodos ASMR (2019). Retrieved from: https://www.youtube.com/channel/UCVU_HZfR3VVdp4pZa2LvWDA.

14. Life with MaK (2019). Socialblade : website. Retrieved from: https://socialblade.com/youtube/c/lifewithmak.

15. Muni E. \& Klyayn D. (2016). Think with Google : website. ASMR: Important Trend on YouTube You Even Haven't Heard about. Retrieved from: https://www.thinkwithgoogle.com/intl/ru-ru/insights-trends/user-insights/asmr-vazhnyi-trend-na-youtube-okotorom-vy-dazhe-ne-slyshali/ [in Russian].

16. Channel ASMR Ppomo (2019). Retrieved from: https://www.youtube.com/channel/UCAtFkapSeoEGPxm5bC3tvaw.

17. The Pure Experience | Michelob ULTRA Pure Gold Super Bowl 2019 (2019). Retrieved from: https://www.youtube.com/watch?v=HKlq-jOvOnw.

18. Colonel Sanders ASMR Video 03: Pocket Squares (2019). Retrieved from: https://www.youtube.com/watch?v=hv7p6uahomc.

19. Oddly IKEA': IKEA ASMR (2019). Retrieved from: https://www.youtube.com/watch?v=uLFaj3Z_tWw\&feature=youtu.be.

20. Agadzhikova, A. IKEA Issued 25-Minutes ASMR-Video. Bird in Flight: website. Retrieved from: https://birdinflight.com/ru/novosti/20170810-ikea-asmr-video.html [in Russian]. 